NBER WORKING PAPER SERIES

\title{
CIGARETTE TAXES AND YOUTH SMOKING: UPDATED ESTIMATES USING YRBS DATA
}

\author{
Benjamin Hansen \\ Joseph J. Sabia \\ Daniel I. Rees \\ Working Paper 21311 \\ http://www.nber.org/papers/w21311 \\ NATIONAL BUREAU OF ECONOMIC RESEARCH \\ 1050 Massachusetts Avenue \\ Cambridge, MA 02138 \\ June 2015
}

The views expressed herein are those of the authors and do not necessarily reflect the views of the National Bureau of Economic Research.

NBER working papers are circulated for discussion and comment purposes. They have not been peerreviewed or been subject to the review by the NBER Board of Directors that accompanies official NBER publications.

(C) 2015 by Benjamin Hansen, Joseph J. Sabia, and Daniel I. Rees. All rights reserved. Short sections of text, not to exceed two paragraphs, may be quoted without explicit permission provided that full credit, including $(\mathcal{C}$ notice, is given to the source. 
Cigarette Taxes and Youth Smoking: Updated Estimates Using YRBS Data

Benjamin Hansen, Joseph J. Sabia, and Daniel I. Rees

NBER Working Paper No. 21311

June 2015

JEL No. H71,I18

\section{ABSTRACT}

Using data from the state and national Youth Risk Behavior Surveys for the period 1991-2005, Carpenter and Cook (2008) found a strong, negative relationship between cigarette taxes and youth smoking. We revisit this relationship using four additional waves of YRBS data (2007, 2009, 2011, and 2013). Our results suggest that youths have become much less responsive to cigarette taxes since 2005. In fact, we find little evidence of a negative relationship between cigarette taxes and youth smoking when we restrict our attention to the period 2007-2013.

Benjamin Hansen

Department of Economics

1285 University of Oregon

Eugene, OR 97403

and NBER

bchansen@uoregon.edu

Joseph J. Sabia

Department of Economics

San Diego State University

5500 Campanile Drive

San Diego, CA 92182

jsabia@mail.sdsu.edu
Daniel I. Rees

University of Colorado Denver

Department of Economics

Campus Box 181

P.O. Box 173364

Denver, CO 80217-3364

Daniel.Rees@ucdenver.edu 


\section{Introduction}

Within the past decade, 31 states have increased their excise tax on cigarettes. Moreover, several of these tax increases have been substantial. For instance, Massachusetts increased its per-pack tax by $\$ 1.00$ in 2008 and Minnesota increased its per-pack tax by $\$ 1.60$ in 2013.

Although often motivated by budgetary shortfalls (Ellis 2008; Dewan 2009), increasing the tax on cigarettes has, according to many experts, the added benefit of discouraging youth smoking (Chaloupka et al. 2011). The strongest evidence to date that cigarette taxes are, in fact, negatively related to youth smoking comes from Carpenter and Cook (2008). Using data from the state and national Youth Risk Behavior Surveys (YRBS) for the period 1991-2005, Carpenter and Cook (hereafter $\mathrm{C} \& \mathrm{C}$ ) found that a one-dollar increase in the per-pack cigarette tax was associated with a 3-6 percentage point reduction in smoking participation among high school students and a 2-4 percentage point reduction in frequent smoking (defined as having smoked on 20 of the past 30 days). ${ }^{1}$

The current study revisits the relationship between cigarette taxes and youth smoking using the same data sources as used by C\&C, the state and national YRBS. Since 2005, the last year of data available to C\&C, four additional waves of YRBS data have been collected (2007, 2009, 2011, and 2013). With these extra data, we update the C\&C estimates of the relationship between cigarette taxes and youth smoking, test to see if this relationship has changed since 2005, and explore the sensitivity of the C\&C estimates and our own updated estimates to various, frequently employed changes in specification.

\footnotetext{
${ }^{1}$ The national YRBS data used by C\&C covered the period 1991-2005; the state YRBS data covered the period 1993-2005. Using local YRBS data for the period 1993-2005, C\&C also presented estimates of the effect of cigarette taxes on $\ln \left(Y_{c} / 1-Y_{c}\right)$, where $Y$ was defined as the proportion of respondents in city $c$ who smoked in the past 30 days. $\mathrm{C} \& \mathrm{C}$ did not translate these estimates into marginal effects.
} 
We highlight three basic results. First, there is a clear negative relationship between cigarette taxes and youth smoking for the period 1991-2013, albeit substantially smaller in magnitude than that found by C\&C. Second, despite the fact that many states have increased their per-pack tax since 2005, the relationship between cigarette taxes and youth smoking appears to have become weaker over time; in fact, when we restrict our attention to the four additional waves of data $(2007,2009,2011,2013)$, there is little evidence that cigarette taxes discourage youth smoking. Third, we find that controlling for state-specific trends eliminates the relationship between cigarette taxes and youth smoking regardless of the period examined. We argue that, by controlling for state-specific trends, we run the risk of discarding informative variation in taxes, but cannot rule out the possibility that the state-specific trends capture unobservable changes in, for instance, preferences that are correlated with both the cigarette tax and youth smoking.

We conclude by noting that youth smoking participation fell precipitously from the late 1990s to the mid-2000s. In 1997, more than one-third of high school students were smokers; by 2005, only 23 percent of high school students reported having smoked a cigarette within the last 30 days. $^{2}$ We speculate that anti-smoking efforts undertaken prior to 2005-including substantial cigarette tax increases passed by many states in the late 1990s and early 2000 s - may have discouraged all but the most price-insensitive youth from experimenting with tobacco. Another possibility is that an increasing reliance on social sources and online vendors (Fix et al. 2006; Hansen et al. 2013) has helped insulate teenagers from anti-smoking policies.

\footnotetext{
${ }^{2}$ These figures are based on weighted national YRBS data. Respondents to the YRBS were asked, "During the past 30 days, on how many days did you smoke cigarettes?" In 1997, 36.4 percent of respondents answered that they had smoked cigarettes on at least one day during the last month. By 2005, only 23.0 percent of respondents reported having smoked in the past month.
} 


\section{Background}

The relationship between cigarette taxes and youth smoking has received a fair amount of attention from researchers. Despite this fact, a consensus view has not been reached. For instance, a recent review by Bader, Boisclair and Ferrence (2011) concluded that cigarette taxes discouraged teenagers and young adults from smoking (p. 4123); in contrast, Guindon (2013, p. 13), who reviewed basically the same literature, concluded "existing studies do not provide strong evidence that tobacco prices or taxes affect smoking onset”.

Although this is a crowded literature, the C\&C study arguably stands out in terms of quality. While many of the studies published prior to 2008 relied on cross-sectional data, C\&C relied on within-state variation in cigarette taxes. As noted by DeCicca, Kenkel and Mathios (2002, pp. 148-149) and others, the cross-sectional relationship between cigarette taxes and youth smoking is likely biased due to difficult-to-measure factors such as antismoking sentiment at the state level.

Moreover, $\mathrm{C} \& \mathrm{C}$ were able to exploit substantial within-state changes in the cigarette tax. During the period 1991-2005, 48 states increased how much they taxed cigarettes; 40 of these 49 states increased their per-pack tax by more than $\$ 0.25$ (in 2005 dollars), and 27 increased their per-pack tax by more than $\$ 0.50 .^{3}$ In comparison, 47 states increased their per-pack tax during the period 1970-1990, but only two increased it by more than $\$ 0.50$ (in 2005 dollars).

Finally, $\mathrm{C} \& \mathrm{C}$ were the first researchers in this literature to use state YRBS data. The state YRBS data are school-based and contain many of the same questions as the national YRBS.

\footnotetext{
${ }^{3}$ For these state counts and all subsequent counts, the District of Columbia is counted as a state
} 
They are coordinated by the Centers for Disease Control (CDC) and are typically administered by state health departments to high school students every other year. As noted by $\mathrm{C} \& \mathrm{C}$, one of the advantages to using these data is that they are representative at the state level.

\section{Data and methods}

Our analysis draws on state and national YRBS data at the individual level for the period 1991-2013. Appendix Tables 1 and 2 report observations by state and year. A total of 45 states conducted at least two surveys during this period, gave the CDC permission to distribute their data, or were willing to provide their data directly to us. On average, we have access to data from 21 state YRBS surveys per year during the period 1991-2005, and 40 state YRBS surveys per year during the period 2007-2013. ${ }^{4}$

Although intended to be nationally representative, not all 50 states contributed data to any given wave of the national YRBS. In fact, between 1991 and 2013, only 5 states contributed data to the national YRBS every year (California, Georgia, Michigan, New York, and Texas). On average, 27 states contributed national YRBS data in any given year during the period 1991-2005. During the period 2007-2013, an average of 26 states contributed national YRBS data in any given year. ${ }^{5}$

Following $\mathrm{C} \& \mathrm{C}$, we use the data described above to estimate a standard logit model in which an indicator of smoking (or frequent smoking), $S$, is equal to 1 if an unobserved variable,

\footnotetext{
${ }^{4}$ When we restrict our analysis to states that conducted (and made available) state YRBS surveys at least three times during the period 1991-2005 and at least three times during the period 2007-2013, our results are similar to those reported below.

${ }^{5}$ A total of 48 states contributed data to the national YRBS during the period 1991-2013. Each of these states increased its nominal tax on cigarettes at least once during this period. As noted above, 45 states contributed data to the state YRBS analysis. Again, each of these states increased its nominal cigarette tax at least once. During the period 2007-2013, 31 states increased their tax on cigarettes; the average per-pack increase was $\$ 0.46$ (in 2005 dollars). In comparison, during the period 1991-2005, 49 states increased their nominal excise tax on cigarettes and the average per-pack increase was $\$ 0.28$ (in 2005 dollars). When we restrict our analysis to states that contributed data to the national YRBS at least three times during the period 1991-2005 and at least three times during the period 2007-2013, our results are qualitatively unchanged from those reported below.
} 
$S^{*}$, is positive. Although $S^{*}$ is unobserved, it is related to a set of observable variables by the equation:

$$
S_{i s t}^{*}=\alpha_{0}+\alpha_{1} \operatorname{Tax}_{s t}+\boldsymbol{X}_{i s t} \boldsymbol{\beta}+v_{s}+z_{t}+\varepsilon_{i s t},
$$

where $\underline{i}$ indexes respondents, $s$ indexes states, $t$ indexes years, and the distribution of $\varepsilon_{i}$ is logistic.

State fixed effects are represented by $v_{s}$ and year fixed effects are represented by $z_{t}$. The

independent variable of interest is $\operatorname{Tax}$, equal to the per-pack excise tax on cigarettes in 2005

dollars. The vector $\boldsymbol{X}$ includes measures of race, sex, age and grade. In addition, we control for the state unemployment rate and 6 clean indoor air law indicators. ${ }^{6}$

\section{Results}

Table 1 presents estimates of equation (1) based on the state YRBS data. Marginal effects, $\delta \operatorname{Pr}(S=1) / \delta \operatorname{Tax}$, are reported and standard errors are corrected for clustering at the state level.

In the first column of Table 1, we restrict our attention to state YRBS surveys conducted during the period 1991-2005. A one-dollar tax increase is associated with a 2.6 percentage point decrease in smoking participation and a 1.9 percentage point decrease in frequent smoking. The semi-elasticities based on these estimates are -9.7 and -14.8 , respectively. ${ }^{7}$

\footnotetext{
${ }^{6}$ Information on clean indoor air laws is available from the ImpacTeen program sponsored by the Robert Wood Johnson Foundation at http://www.impacteen.org/tobaccodata.htm. The indicators are for whether the state restricted smoking in private sector buildings, government buildings, restaurants, shopping areas, public schools and private schools. Appendix Table 3 reports descriptive statistics.

${ }^{7}$ In other words, a one-dollar increase in the cigarette tax is associated with a 9.7 percent decrease in smoking participation and a 14.8 percent decrease in frequent smoking. Using aggregate state YRBS data for the period 1993-2005, C\&C found that a one-dollar increase in the cigarette tax was associated with a 2.7 percentage point decrease in smoking participation and a 2.4 percentage point decrease in frequent smoking. The corresponding semi-elasticites were -9.2 and -17.8 (Carpenter and Cook 2008, p. 294).
} 
In the second column of Table 1, we include the additional four waves of state YRBS data and our estimates of $\alpha_{1}$ shrink considerably. Specifically, for the period 1991-2013, a onedollar tax increase is associated with a 1.0 percentage point decrease in smoking participation and a 0.7 percentage point decrease in frequent smoking. The semi-elasticities are -4.8 and -7.6 , roughly half the magnitude of the semi-elasticities obtained for the period 1991-2005. ${ }^{8}$

In the third column of Table 1, we restrict our attention to the four additional waves of YRBS data $(2007,2009,2011,2013)$. The estimated relationship between taxes and youth smoking is actually positive during the period 2007-2013: a one-dollar increase in the tax is associated with a (statistically insignificant) 0.7 percentage point increase in smoking participation and a (statistically insignificant) 0.2 percentage point increase in frequent smoking. We can formally reject the hypothesis that $\alpha_{1}$ was stable across the two periods (1991-2005 vs. 2007-2013) for both smoking participation and frequent smoking.

Table 2 presents estimates of equation (1) based on the weighted national YRBS data. In column (1) of Table 2, we focus on data collected between 1991 and 2005, the period examined by $\mathrm{C} \& \mathrm{C}$. We find that a one-dollar tax increase is associated with a 4.6 percentage point decrease in smoking participation and a 2.6 percentage point decrease in frequent smoking. ${ }^{9}$ The semi-elasticities based on these estimates are -15.5 and -19.1 , respectively. When the four additional waves of data are included in the analysis, a one-dollar tax increase is associated with

\footnotetext{
${ }^{8}$ In Appendix Tables 4-6, we report estimates of equation (1) for 1991-2005, 1991-2007, 1991-2009, 1991-20011, and 1991-2013. With only a few exceptions, the relationship between taxes and smoking shrinks as additional waves of data are included.

${ }^{9}$ Using national YRBS data for the period 1991-2005, C\&C found that a one-dollar increase in the cigarette tax was associated with a 5.9 percentage point decrease in smoking participation and a 4.1 percentage point decrease in frequent smoking. The $\mathrm{C} \& \mathrm{C}$ results were based on weighted national data, which we use in Table 2. In Appendix Table 7, we report estimates of equation (1) based on unweighted national data. For the period 1991-2005, a onedollar increase in the cigarette tax is associated with a 3.8 percentage point decrease in smoking participation and a (statistically insignificant) 1.9 percentage point decrease in frequent smoking.
} 
a 2.8 percentage point decrease in smoking participation and a 1.6 percentage point decrease in frequent smoking; the corresponding semi-elasticities are -10.9 and -14.1. If we restrict our attention to the period 2007-2013, a one-dollar tax increase is associated with a (statistically insignificant) 1.1 percentage point decrease in smoking participation and a (statistically insignificant) 0.6 percentage point decrease in frequent smoking. We cannot, however, formally reject the hypothesis that $\alpha_{l}$ was stable across the two periods.

Finally, in Table 3 we combine the national and state YRBS data in an effort to exploit as much identifying variation as possible. For the period 1991-2005, a one-dollar tax increase is associated with a 3.0 percentage point decrease in smoking participation and a 1.9 percentage point decrease in frequent smoking. When the additional waves of data are included, these estimates fall by more than 50 percent, as do the corresponding semi-elasticities. When we focus just on the period 2007-2013, the relationship between taxes and youth smoking is again positive: a one-dollar tax increase is associated with a (statistically insignificant) 0.7 percentage point increase in smoking participation and a (statistically insignificant) 0.2 percentage point increase in frequent smoking. We can reject the hypothesis that the relationship between smoking and taxes was stable across the two periods.

\section{Adding state-specific trends}

Equation (1) can be modified to include state-specific linear trends, which are intended to capture the effects of omitted factors at the state level that evolved at a constant rate such as anti- 
smoking sentiment. It should be noted, however, that by including state-specific trends, we run the risk of discarding potentially valid (i.e., exogenous) variation. ${ }^{10}$

In general, including state-specific linear trends produces much smaller estimates of the relationship between cigarette taxes and youth smoking (Table 4). For instance, if we restrict our attention to the period 1991-2005 and include state-specific linear trends, a one-dollar tax increase is associated with a (statistically insignificant) 0.7 percentage point decrease in smoking participation. With the four additional waves of data, a one-dollar tax increase is associated with a (statistically insignificant) 0.3 increase in smoking participation percentage points. Including state-specific quadratic trends produces a similar pattern of results (Appendix Tables 8). When we include U.S. Census Region-year interactions, our estimates of $\alpha_{1}$ are smaller than those reported in Table 3, but still significant and negative for the period 1991-2013.

\section{Discussion}

Using state and national YRBS data for the period 1991-2005, Carpenter and Cook (2008) found a strong negative relationship between cigarette taxes and youth smoking. Since 2005, 31 states have increased their cigarette tax and many of these tax increases have been substantial. In this comment, we revisit the relationship between cigarette taxes and youth smoking using four additional waves of YRBS data (2007, 2009, 2011, and 2013).

Our results suggest that the relationship between cigarette taxes and youth smoking has weakened over time. When we combine state and national YRBS data and restrict our attention to the period 1991-2005, a one-dollar tax increase is associated with a 3.0 percentage point

\footnotetext{
${ }^{10}$ This point has been made in the context of examining the relationship between minimum wages and employment (Neumark et al. 2014). A regression of cigarette taxes on a set of state and year fixed effects and the controls shown in Appendix Table 3 produced an R-squared of 0.83 . When we included state-specific linear time trends on the right-hand side of this regression, the R-squared increased to 0.93 .
} 
decrease in smoking participation and a 1.9 percentage point decrease in frequent smoking. When the additional waves of data are included, these estimates fall by more than 50 percent, as do the corresponding semi-elasticities.

Why might youth have become less responsive to cigarette taxes since 2005? In 1997, more than one-third of high school students in the United States reported having smoked at least one cigarette in the past month. By 2005, the youth smoking participation rate had fallen by approximately 10 percentage points. It is possible that anti-smoking efforts undertaken prior to 2005 - including substantial cigarette tax increases passed by many states in the late 1990s and early 2000s—discouraged all but the most price-insensitive youth from experimenting with tobacco. It is also possible that an increasing reliance on social sources and online vendors (Fix et al. 2006; Hansen et al. 2013) has helped insulate teenagers from anti-smoking policies. 


\section{References}

Bader, Pearl, David Boisclair, and Roberta Ferrence. 2011. "Effects of Tobacco Taxation and Pricing on Smoking Behavior in High Risk Populations: A Knowledge Synthesis." International Journal of Environmental Research and Public Health 8: 4118-4139.

Carpenter, Christopher and Cook, Philip J., 2008. "Cigarette Taxes and Youth Smoking: New Evidence from National, State, and Local Youth Risk Behavior Surveys." Journal of Health Economics 27 (2): 287-299.

Chaloupka, Frank J, Kurt Straif, and Maria E Leon. 2011. "Effectiveness of Tax and Price Policies in Tobacco Control." Tobacco Control 20(3): 235-238.

DeCicca, Philip and Donald Kenkel. 2013. "Synthesizing Econometric Evidence: The Case of Price Elasticity Estimates.” Working Paper prepared for Methods for Research Synthesis: A Cross-Disciplinary Workshop, Harvard Center for Risk Analysis.

DeCicca, Philip, Donald Kenkel, and Alan Mathios. 2002. "Putting Out the Fires: Will Higher Taxes Reduce the Onset of Youth Smoking?” Journal of Political Economy 110 (1): 144-169.

DeCicca, Philip, Donald Kenkel, and Alan Mathios. 2008. "Cigarette Taxes and the Transition from Youth to Adult Smoking: Smoking Initiation, Cessation, and Participation.” Journal of Health Economics 27 (4): 904-917.

Dewan, Shaila. 2009. "States Look at Tobacco to Balance the Budget. The New York Times, March 20. Available at: http://www.nytimes.com/2009/03/21/us/21tobacco.html?_r=0

Ellis, Ronnie. 2008. “Gov. Wants Tobacco Tax Increase”. Glasgow Daily Times, December 12. Available at: http://www.glasgowdailytimes.com/news/local_news/gov-wants-tobacco-taxincrease/article_d8215c7d-b5a6-5718-99fc-0304bef83229.html

Fix, Brian V., Margaret Zambon, Cheryl Higbee, K. Michael Cummings, Terry Alford, Andrew Hyland. 2006. "Internet Cigarette Purchasing among 9th Grade Students in Western New York: 2000-2001 vs. 2004-2005." Preventive Medicine 43 (3): 191-195.

Guindon, Godefroy Emmanuel. 2013. "The Impact of Tobacco Prices on Smoking Onset: A Methodological Review." Tobacco Control 23 (2): e5.

Hansen, Benjamin, Daniel I. Rees, and Joseph J. Sabia. 2013. "Cigarette Taxes and How Youth Obtain Cigarettes.” National Tax Journal 66 (2): 371-394.

Neumark, David, J. M. Ian Salas, and William Wascher. 2014. "Revisiting the Minimum WageEmployment Debate: Throwing Out the Baby with the Bathwater?" Industrial and Labor Relations Review 67 (2.5): 608-648. 


\section{Table 1. Logit Estimates of the Relationship between Cigarette Taxes and Youth Smoking Using State YRBS Data}

\begin{tabular}{|c|c|c|c|}
\hline & $1991-2005$ & $1991-2013$ & $2007-2013$ \\
\hline \multicolumn{4}{|l|}{ Panel I: Smoking Participation } \\
\hline Cig Tax & $\begin{array}{l}-.026 * * * \\
(.009)\end{array}$ & $\begin{array}{l}-.010 * * \\
(.005)\end{array}$ & $\begin{array}{c}.007 \\
(.006)\end{array}$ \\
\hline Mean & .267 & .208 & .156 \\
\hline Semi-elasticity & -9.72 & -4.81 & 4.49 \\
\hline Test of equality across periods & \multicolumn{3}{|c|}{$\mathrm{z}$-value $=3.29(\mathrm{p}$-value $=.001)$} \\
\hline \multicolumn{4}{|l|}{ Panel II: Frequent Smoking } \\
\hline Cig Tax & $\begin{array}{l}-.019 * \\
(.006)\end{array}$ & $\begin{array}{l}-.007 * * * \\
(.003)\end{array}$ & $\begin{array}{c}0.002 \\
(0.003)\end{array}$ \\
\hline Mean & .128 & .092 & .060 \\
\hline Semi-elasticity & -14.80 & -7.63 & 3.33 \\
\hline Test of equality across periods & \multicolumn{3}{|c|}{$\mathrm{z}$-value $=3.38(\mathrm{p}$-value $=.001)$} \\
\hline Year and state fixed effects & yes & yes & yes \\
\hline $\mathrm{N}$ & 409,385 & 883,691 & 474,306 \\
\hline \multicolumn{4}{|c|}{$*$ Statistically significant at $10 \%$ level; $* *$ at $5 \%$ level; $* * *$ at $1 \%$ level. } \\
\hline $\begin{array}{l}\text { Notes: Marginal effects based on unwe } \\
\text { unemployment rate, clean air laws, der } \\
\text { state are in parentheses. }\end{array}$ & $\begin{array}{l}\text { RBS data are } \\
\text { nd state and ye }\end{array}$ & $\begin{array}{l}\text { All regression } \\
\text { ffects. Standar }\end{array}$ & $\begin{array}{l}\text { le the } \\
\text { clustered by }\end{array}$ \\
\hline
\end{tabular}


Table 2. Logit Estimates of the Relationship between Cigarette Taxes and Youth Smoking Using National YRBS Data

\begin{tabular}{llcc}
\hline Panel I: Smoking Participation & $1991-2005$ & $1991-2013$ & $2007-2013$ \\
\hline Cig Tax & & & \\
& $(.022)$ & $-.028 * * *$ & -.011 \\
Mean & .297 & $.009)$ & $(.020)$ \\
Semi-elasticity & -15.48 & -10.85 & -175 \\
Test of equality across periods & z-value $=.94$ (p-value $=0.347)$ \\
\hline
\end{tabular}

\section{Panel II: Frequent Smoking}

\begin{tabular}{|c|c|c|c|}
\hline Cig Tax & $\begin{array}{l}-.026^{*} \\
(.014)\end{array}$ & $\begin{array}{l}-.016 * * * \\
(0.006)\end{array}$ & $\begin{array}{l}-0.006 \\
(0.015)\end{array}$ \\
\hline Mean & .136 & .113 & .060 \\
\hline Semi-elasticity & -19.06 & -14.14 & -10.00 \\
\hline Test of equality across periods & \multicolumn{3}{|c|}{$\mathrm{z}$-value $=.58(\mathrm{p}$-value $=.561)$} \\
\hline Year and state fixed effects & yes & yes & yes \\
\hline $\mathrm{N}$ & 103,408 & 158,605 & 55,197 \\
\hline \multicolumn{4}{|c|}{$*$ Statistically significant at $10 \%$ level; $* *$ at $5 \%$ level; $* * *$ at $1 \%$ level. } \\
\hline \multicolumn{4}{|c|}{$\begin{array}{l}\text { Notes: Marginal effects based on weighted national YRBS data are reported. All regressions include the } \\
\text { unemployment rate, clean air laws, demographics, and state and year fixed effects. Standard errors clustered by } \\
\text { state are in parentheses. }\end{array}$} \\
\hline
\end{tabular}




\section{Table 3. Logit Estimates of the Relationship between Cigarette Taxes and Youth Smoking Using Combined State and National YRBS Data}

\begin{tabular}{|c|c|c|c|}
\hline & $1991-2005$ & $1991-2013$ & $2007-2013$ \\
\hline \multicolumn{4}{|l|}{ Panel I: Smoking Participation } \\
\hline Cig Tax & $\begin{array}{l}-.030 * * * \\
(.008)\end{array}$ & $\begin{array}{l}-.011 * * \\
(.005)\end{array}$ & $\begin{array}{c}.007 \\
(.006)\end{array}$ \\
\hline Mean & .269 & .213 & .158 \\
\hline Semi-elasticity & -11.15 & -5.15 & 4.43 \\
\hline Test of equality across periods & \multicolumn{3}{|c|}{ z-value $=3.46(p$-value $=.001)$} \\
\hline \multicolumn{4}{|l|}{ Panel II: Frequent Smoking } \\
\hline Cig Tax & $\begin{array}{l}-.019 * * * \\
(.004)\end{array}$ & $\begin{array}{l}-.007 * * * \\
(.002)\end{array}$ & $\begin{array}{c}.002 \\
(.003)\end{array}$ \\
\hline Mean & .125 & .092 & .060 \\
\hline Semi-elasticity & -15.19 & -7.57 & 3.33 \\
\hline Test of equality across periods & \multicolumn{3}{|c|}{$\mathrm{z}$-value $=3.29(\mathrm{p}$-value $=.001)$} \\
\hline Year and state fixed effects & yes & yes & yes \\
\hline $\mathrm{N}$ & 512,793 & $1,042,296$ & 529,503 \\
\hline \multicolumn{4}{|c|}{$*$ Statistically significant at $10 \%$ level; $* *$ at $5 \%$ level; $* * *$ at $1 \%$ level. } \\
\hline \multicolumn{4}{|c|}{$\begin{array}{l}\text { Notes: Marginal effects based on unweighted state and national YRBS data are reported. All regressions include } \\
\text { the unemployment rate, clean air laws, demographics, and state and year fixed effects. Standard errors clustered } \\
\text { by state are in parentheses. }\end{array}$} \\
\hline
\end{tabular}




\section{Table 4. Logit Estimates of the Relationship between Cigarette Taxes and Youth Smoking Controlling for State-Specific Linear Time Trends}

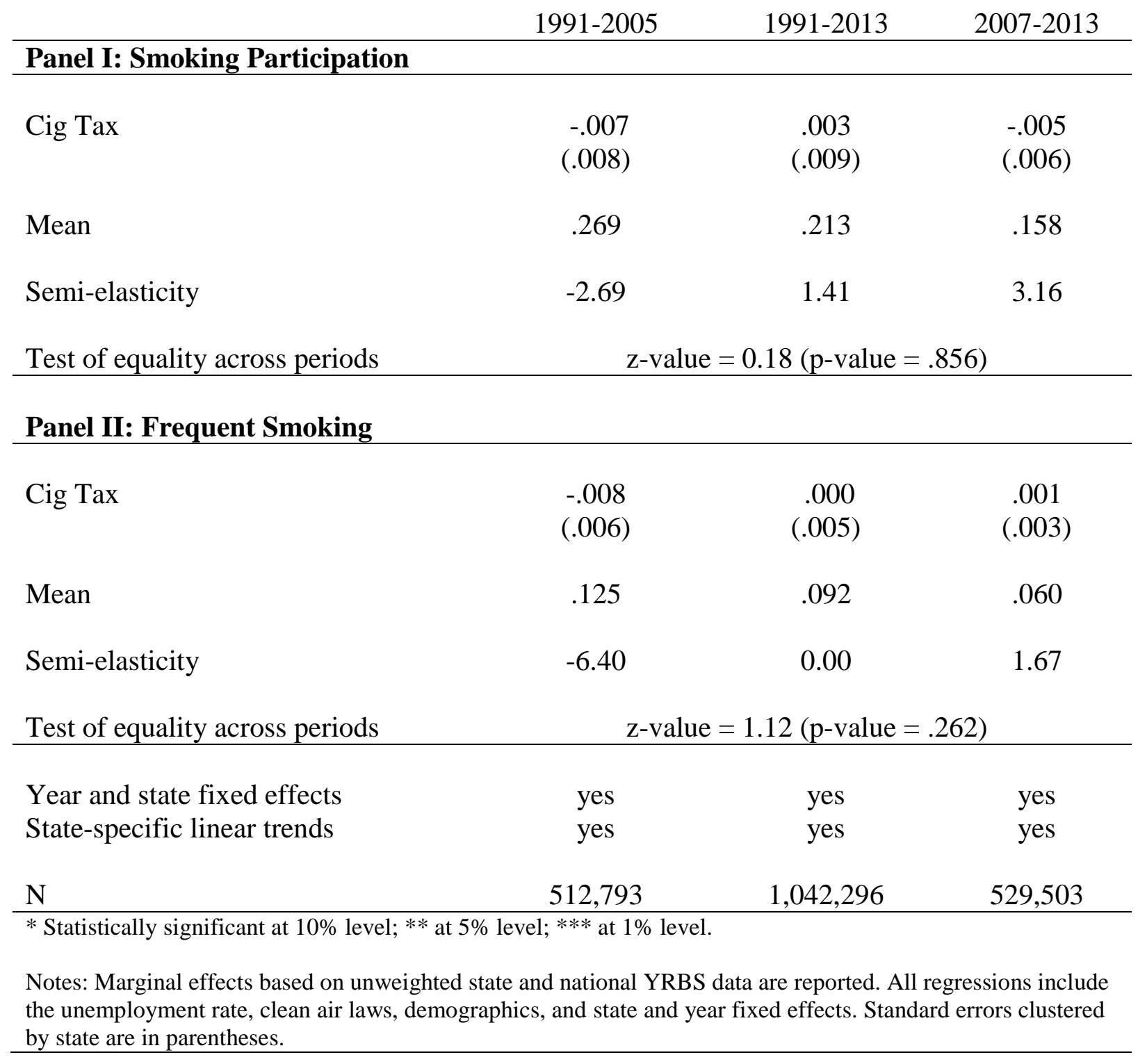


Appendix Table 1. National YRBS State by Year Observation Count

\begin{tabular}{|c|c|c|c|c|c|c|c|c|c|c|c|c|c|}
\hline & 1991 & 1993 & 1995 & 1997 & 1999 & 2001 & 2003 & 2005 & 2007 & 2009 & 2011 & 2013 & Total \\
\hline$A L A B A M A$ & 0 & 761 & 96 & 707 & 58 & 301 & 607 & 0 & 461 & 1,016 & 309 & 311 & 4,627 \\
\hline ARIZONA & 0 & 426 & 0 & 1,028 & 129 & 396 & 328 & 271 & 499 & 344 & 1,083 & 172 & 4,676 \\
\hline ARKANSAS & 0 & 372 & 282 & 342 & 0 & 0 & 270 & 0 & 393 & 294 & 0 & 299 & 2,252 \\
\hline CALIFORNIA & 1,677 & 1,900 & 630 & 1,857 & 2,410 & 2,079 & 1,626 & 1,477 & 2,005 & 2,687 & 1,796 & 2,377 & 22,521 \\
\hline COLORADO & 141 & 254 & 99 & 255 & 0 & 620 & 0 & 0 & 0 & 189 & 275 & 274 & 2,107 \\
\hline CONNECTICUT & 0 & 0 & 228 & 201 & 0 & 0 & 0 & 224 & 0 & 0 & 0 & 61 & 714 \\
\hline DELAWARE & 0 & 0 & 209 & 0 & 0 & 0 & 353 & 0 & 0 & 0 & 226 & 0 & 788 \\
\hline D.C. & 0 & 0 & 474 & 0 & 0 & 0 & 0 & 0 & 0 & 0 & 297 & 0 & 771 \\
\hline FLORIDA & 1,143 & 0 & 520 & 649 & 824 & 1,026 & 1,435 & 517 & 719 & 220 & 1,372 & 952 & 9,377 \\
\hline GEORGIA & 466 & 879 & 421 & 322 & 789 & 468 & 391 & 1,765 & 338 & 1,272 & 123 & 352 & 7,586 \\
\hline$H A W A I I$ & 0 & 0 & 0 & 0 & 303 & 0 & 0 & 0 & 0 & 0 & 0 & 0 & 303 \\
\hline IDAHO & 0 & 0 & 0 & 0 & 0 & 144 & 0 & 228 & 0 & 0 & 259 & 251 & 882 \\
\hline ILLINOIS & 394 & 264 & 232 & 0 & 218 & 409 & 300 & 462 & 561 & 1,405 & 950 & 620 & 5,815 \\
\hline INDIANA & 263 & 0 & 0 & 0 & 0 & 170 & 403 & 162 & 391 & 0 & 261 & 802 & 2,452 \\
\hline IOWA & 0 & 0 & 239 & 732 & 0 & 0 & 0 & 232 & 241 & 0 & 0 & 0 & 1,444 \\
\hline KANSAS & 0 & 166 & 0 & 199 & 0 & 0 & 297 & 271 & 0 & 193 & 293 & 190 & 1,609 \\
\hline KENTUCKY & 0 & 0 & 341 & 0 & 0 & 0 & 0 & 514 & 348 & 0 & 208 & 647 & 2,058 \\
\hline LOUISIANA & 0 & 0 & 731 & 536 & 586 & 0 & 645 & 141 & 0 & 413 & 0 & 0 & 3,052 \\
\hline MAINE & 0 & 241 & 149 & 231 & 192 & 201 & 187 & 0 & 0 & 0 & 0 & 0 & 1,201 \\
\hline$M A R Y L A N D$ & 200 & 141 & 0 & 759 & 0 & 0 & 247 & 0 & 0 & 0 & 0 & 501 & 1,848 \\
\hline MASSACHUSETTS & 0 & 347 & 270 & 1,522 & 0 & 248 & 208 & 248 & 696 & 0 & 279 & 0 & 3,818 \\
\hline MICHIGAN & 712 & 136 & 1,059 & 473 & 502 & 318 & 388 & 287 & 284 & 312 & 605 & 469 & 5,545 \\
\hline MINNESOTA & 0 & 317 & 0 & 0 & 0 & 0 & 0 & 93 & 0 & 185 & 0 & 290 & 885 \\
\hline MISSISSIPPI & 462 & 348 & 469 & 302 & 623 & 324 & 0 & 0 & 331 & 0 & 91 & 560 & 3,510 \\
\hline
\end{tabular}




\begin{tabular}{|c|c|c|c|c|c|c|c|c|c|c|c|c|c|}
\hline MISSOURI & 237 & 178 & 534 & 0 & 546 & 449 & 253 & 99 & 337 & 81 & 332 & 266 & 3,312 \\
\hline MONTANA & 0 & 0 & 0 & 0 & 0 & 168 & 0 & 0 & 0 & 0 & 0 & 0 & 168 \\
\hline NEBRASKA & 0 & 391 & 0 & 0 & 0 & 0 & 0 & 0 & 0 & 0 & 0 & 0 & 391 \\
\hline NEVADA & 0 & 0 & 0 & 0 & 0 & 228 & 0 & 0 & 0 & 381 & 195 & 0 & 804 \\
\hline NEW HAMPSHIRE & 248 & 0 & 0 & 0 & 0 & 0 & 0 & 0 & 0 & 0 & 0 & 0 & 248 \\
\hline NEW JERSEY & 429 & 0 & 0 & 682 & 231 & 208 & 286 & 294 & 668 & 471 & 111 & 354 & 3,734 \\
\hline NEW MEXICO & 248 & 640 & 0 & 260 & 0 & 144 & 99 & 0 & 213 & 583 & 0 & 0 & 2,187 \\
\hline NEW YORK & 354 & 479 & 268 & 336 & 695 & 291 & 878 & 454 & 895 & 1,139 & 622 & 372 & 6,783 \\
\hline NORTH CAROLINA & 0 & 294 & 109 & 313 & 493 & 651 & 0 & 630 & 544 & 0 & 1,067 & 365 & 4,466 \\
\hline OHIO & 130 & 513 & 540 & 500 & 546 & 219 & 278 & 261 & 0 & 0 & 0 & 155 & 3,142 \\
\hline OKLAHOMA & 0 & 0 & 0 & 212 & 0 & 388 & 0 & 226 & 269 & 0 & 0 & 0 & 1,095 \\
\hline OREGON & 0 & 185 & 0 & 0 & 0 & 181 & 0 & 265 & 0 & 239 & 0 & 0 & 870 \\
\hline PENNSYLVANIA & 465 & 351 & 638 & 255 & 477 & 0 & 310 & 391 & 206 & 1,036 & 417 & 256 & 4,802 \\
\hline RHODE ISLAND & 0 & 0 & 0 & 0 & 70 & 0 & 0 & 0 & 0 & 0 & 0 & 0 & 70 \\
\hline SOUTH CAROLINA & 274 & 385 & 0 & 484 & 769 & 0 & 839 & 271 & 0 & 0 & 0 & 0 & 3,022 \\
\hline SOUTH DAKOTA & 266 & 0 & 0 & 0 & 0 & 0 & 290 & 0 & 0 & 0 & 0 & 0 & 556 \\
\hline TENNESSEE & 0 & 497 & 0 & 546 & 263 & 584 & 0 & 387 & 156 & 0 & 282 & 0 & 2,715 \\
\hline$T E X A S$ & 2,392 & 1,300 & 1,152 & 896 & 2,622 & 1,941 & 2,460 & 1,651 & 1,487 & 1,286 & 1,690 & 380 & 19,257 \\
\hline UTAH & 0 & 0 & 0 & 0 & 0 & 0 & 173 & 271 & 196 & 0 & 0 & 0 & 640 \\
\hline VERMONT & 137 & 0 & 0 & 0 & 0 & 0 & 227 & 0 & 0 & 0 & 0 & 0 & 364 \\
\hline VIRGINIA & 664 & 0 & 62 & 0 & 714 & 0 & 231 & 340 & 421 & 97 & 195 & 1,080 & 3,804 \\
\hline WASHINGTON & 413 & 373 & 82 & 102 & 0 & 47 & 0 & 100 & 0 & 242 & 161 & 192 & 1,712 \\
\hline WEST VIRGINIA & 0 & 294 & 0 & 0 & 0 & 257 & 0 & 222 & 234 & 450 & 249 & 0 & 1,706 \\
\hline WISCONSIN & 0 & 0 & 0 & 275 & 525 & 232 & 176 & 235 & 175 & 662 & 636 & 0 & 2,916 \\
\hline Total & 11,715 & 12,432 & 9,834 & 14,976 & 14,585 & 12,692 & 14,185 & 12,989 & 13,068 & 15,197 & 14,384 & 12,548 & 158,605 \\
\hline
\end{tabular}


Appendix Table 2. State YRBS State by Year Observation Count

\begin{tabular}{|c|c|c|c|c|c|c|c|c|c|c|c|c|c|}
\hline & 1991 & 1993 & 1995 & 1997 & 1999 & 2001 & 2003 & 2005 & 2007 & 2009 & 2011 & 2013 & Total \\
\hline$A L A B A M A$ & 2,294 & 0 & 3,695 & 3,543 & 1,980 & 1,437 & 1,005 & 1,006 & 0 & 1,329 & 1,292 & 1,416 & 18,997 \\
\hline$A L A S K A$ & 0 & 0 & 0 & 0 & 0 & 0 & 1,387 & 0 & 1,205 & 1,172 & 1,203 & 1,125 & 6,092 \\
\hline ARIZONA & 0 & 0 & 0 & 0 & 0 & 0 & 3,201 & 2,997 & 2,694 & 2,303 & 2,563 & 1,470 & 15,228 \\
\hline ARKANSAS & 0 & 0 & 2,166 & 1,885 & 1,407 & 1,614 & 0 & 1,406 & 1,463 & 1,507 & 1,244 & 1,366 & 14,058 \\
\hline COLORADO & 0 & 0 & 0 & 0 & 0 & 0 & 0 & 1,417 & 0 & 1,399 & 1,370 & 0 & 4,186 \\
\hline CONNECTICUT & 0 & 0 & 0 & 1,671 & 0 & 0 & 0 & 2,085 & 1,984 & 2,310 & 1,992 & 2,305 & 12,347 \\
\hline DELAWARE & 0 & 0 & 0 & 0 & 2,267 & 2,750 & 2,887 & 2,548 & 2,275 & 2,162 & 2,112 & 2,461 & 19,462 \\
\hline FLORIDA & 0 & 0 & 0 & 0 & 0 & 0 & 3,829 & 4,273 & 4,219 & 5,193 & 5,933 & 5,746 & 29,193 \\
\hline GEORGIA & 2,116 & 1,549 & 0 & 0 & 0 & 0 & 1,919 & 1,582 & 2,256 & 1,706 & 1,722 & 1,727 & 14,577 \\
\hline IDAHO & 0 & 0 & 0 & 0 & 0 & 1,604 & 1,651 & 1,374 & 1,317 & 2,020 & 1,610 & 1,794 & 11,370 \\
\hline ILLINOIS & 0 & 0 & 0 & 0 & 0 & 0 & 0 & 0 & 2,239 & 2,736 & 3,216 & 2,943 & 11,134 \\
\hline INDIANA & 0 & 0 & 0 & 0 & 0 & 0 & 1,542 & 1,452 & 2,172 & 1,423 & 2,659 & 0 & 9,248 \\
\hline$I O W A$ & 0 & 0 & 0 & 0 & 0 & 0 & 0 & 1,324 & 1,388 & 0 & 1,482 & 0 & 4,194 \\
\hline KANSAS & 0 & 0 & 0 & 0 & 0 & 0 & 0 & 1,580 & 1,624 & 1,931 & 1,749 & 1,813 & 8,697 \\
\hline KENTUCKY & 0 & 0 & 0 & 0 & 0 & 0 & 1,495 & 3,073 & 3,238 & 1,621 & 1,639 & 1,495 & 12,561 \\
\hline LOUISIANA & 0 & 0 & 0 & 0 & 0 & 0 & 0 & 0 & 1,201 & 916 & 1,004 & 943 & 4,064 \\
\hline MAINE & 0 & 0 & 1,342 & 1,761 & 0 & 1,252 & 1,550 & 1,262 & 1,224 & 7,987 & 8,695 & 7,874 & 32,947 \\
\hline$M A R Y L A N D$ & 0 & 0 & 0 & 0 & 0 & 0 & 0 & 1,341 & 1,382 & 1,488 & 2,540 & 48,111 & 54,862 \\
\hline MASSACHUSETTS & 0 & 3,137 & 3,970 & 3,800 & 4,156 & 3,808 & 3,298 & 3,067 & 2,899 & 2,521 & 2,540 & 2,594 & 35,790 \\
\hline MICHIGAN & 0 & 0 & 0 & 4,144 & 2,508 & 3,282 & 3,160 & 3,033 & 3,239 & 3,097 & 3,894 & 3,930 & 30,287 \\
\hline MISSISSIPPI & 0 & 1,394 & 1,214 & 1,412 & 1,538 & 1,686 & 1,419 & 0 & 1,462 & 1,684 & 1,719 & 1,456 & 14,984 \\
\hline MISSOURI & 0 & 0 & 4,682 & 1,407 & 1,590 & 1,584 & 1,490 & 1,813 & 1,465 & 1,540 & 0 & 1,505 & 17,076 \\
\hline MONTANA & 0 & 2,405 & 2,413 & 2,443 & 2,798 & 2,422 & 2,513 & 2,815 & 3,689 & 1,715 & 3,859 & 4,565 & 31,637 \\
\hline$N E B R A S K A$ & 2,278 & 3,113 & 0 & 0 & 0 & 0 & 2,623 & 3,505 & 0 & 0 & 3,570 & 1,731 & 16,820 \\
\hline NEVADA & 0 & 1,943 & 1,472 & 1,410 & 1,638 & 1,380 & 1,892 & 1,474 & 1,686 & 1,948 & 0 & 1,959 & 16,802 \\
\hline NEW HAMPSHIRE & 0 & 2,589 & 2,079 & 0 & 0 & 0 & 1,276 & 1,230 & 1,585 & 1,450 & 1,362 & 1,568 & 13,139 \\
\hline NEW JERSEY & 0 & 0 & 0 & 0 & 0 & 1,965 & 0 & 1,460 & 0 & 1,692 & 1,582 & 1,622 & 8,321 \\
\hline
\end{tabular}




\begin{tabular}{|c|c|c|c|c|c|c|c|c|c|c|c|c|c|}
\hline NEW MEXICO & 2,776 & 0 & 0 & 0 & 0 & 0 & 0 & 5,022 & 2,368 & 4,562 & 5,362 & 4,996 & 25,086 \\
\hline NEW YORK & 0 & 0 & 0 & 3,575 & 3,261 & 0 & 8,663 & 8,985 & 12,192 & 13,289 & 12,099 & 9,620 & 71,684 \\
\hline $\begin{array}{l}\text { NORTH } \\
\text { CAROLINA }\end{array}$ & 0 & 2,664 & 1,888 & 0 & 0 & 2,408 & 2,422 & 3,761 & 3,346 & 5,445 & 2,161 & 1,758 & 25,853 \\
\hline NORTH DAKOTA & 0 & 0 & 0 & 0 & 1,730 & 1,495 & 1,562 & 1,631 & 1,636 & 1,737 & 1,799 & 1,843 & 13,433 \\
\hline $\mathrm{OHIO}$ & 0 & 2,373 & 0 & 2,111 & 1,968 & 0 & 1,133 & 1,323 & 2,355 & 0 & 1,281 & 1,416 & 13,960 \\
\hline OKLAHOMA & 0 & 0 & 0 & 0 & 0 & 0 & 1,316 & 1,632 & 2,490 & 1,361 & 1,111 & 1,428 & 9,338 \\
\hline PENNSYLVANIA & 0 & 0 & 0 & 0 & 0 & 0 & 0 & 0 & 0 & 1,977 & 0 & 0 & 1,977 \\
\hline RHODE ISLAND & 0 & 0 & 0 & 1,433 & 0 & 1,303 & 1,705 & 2,206 & 2,014 & 2,940 & 3,585 & 2,250 & 17,436 \\
\hline $\begin{array}{l}\text { SOUTH } \\
\text { CAROLINA }\end{array}$ & 5,286 & 4,507 & 5,165 & 5,175 & 4,302 & 0 & 0 & 1,198 & 1,122 & 1,007 & 1,304 & 1,476 & 30,542 \\
\hline SOUTH DAKOTA & 1,287 & 1,302 & 1,132 & 1,519 & 1,598 & 1,448 & 1,682 & 1,479 & 1,452 & 2,012 & 0 & 1,210 & 16,121 \\
\hline TENNESSEE & 0 & 3,200 & 0 & 0 & 0 & 0 & 1,850 & 1,472 & 1,952 & 2,122 & 2,499 & 1,719 & 14,814 \\
\hline TEXAS & 0 & 0 & 0 & 0 & 0 & 6,587 & 0 & 3,880 & 3,162 & 3,324 & 3,771 & 2,889 & 23,613 \\
\hline UTAH & 4,353 & 4,309 & 3,139 & 1,337 & 0 & 1,013 & 1,371 & 1,455 & 1,829 & 1,505 & 1,597 & 2,057 & 23,965 \\
\hline VERMONT & 0 & 0 & 0 & 0 & 8,550 & 8,937 & 7,876 & 9,059 & 7,294 & 9,884 & 8,123 & 0 & 59,723 \\
\hline VIRGINIA & 0 & 0 & 0 & 0 & 0 & 0 & 0 & 0 & 0 & 0 & 1,329 & 6,338 & 7,667 \\
\hline WEST VIRGINIA & 0 & 2,729 & 2,007 & 1,751 & 1,440 & 0 & 1,655 & 1,301 & 1,299 & 1,499 & 2,031 & 1,702 & 17,414 \\
\hline WISCONSIN & 0 & 3,169 & 0 & 1,239 & 1,250 & 1,955 & 1,997 & 2,264 & 1,986 & 2,333 & 2,863 & 2,691 & 21,747 \\
\hline WYOMING & 0 & 0 & 1,629 & 1,916 & 1,589 & 2,643 & 1,480 & 2,310 & 2,035 & 2,633 & 2,265 & 2,745 & 21,245 \\
\hline Total & 20,390 & 40,383 & 37,993 & 43,532 & 45,570 & 52,573 & 72,849 & 96,095 & 96,438 & 112,480 & 115,731 & 149,657 & 883,691 \\
\hline
\end{tabular}


Appendix Table 3. Summary Statistics for Combined State and National YRBS

\begin{tabular}{|c|c|c|c|c|c|}
\hline Dependent Variables & 1991-2005 & 1991-2007 & 1991-2009 & 1991-2011 & $1991-2013$ \\
\hline \multirow[t]{2}{*}{ Smoking Participation } & 0.269 & 0.254 & 0.241 & 0.228 & 0.213 \\
\hline & $(0.443)$ & $(0.436)$ & $(0.428)$ & $(0.420)$ & $(0.410)$ \\
\hline \multirow[t]{2}{*}{ Frequent Smoking } & 0.125 & 0.117 & 0.108 & 0.101 & 0.092 \\
\hline & $(0.331)$ & $(0.321)$ & $(0.311)$ & $(0.301)$ & $(0.290)$ \\
\hline \multirow[t]{2}{*}{ Everyday Smoking } & 0.094 & 0.088 & 0.082 & 0.076 & 0.069 \\
\hline & $(0.292)$ & $(0.283)$ & $(0.274)$ & $(0.265)$ & $(0.254)$ \\
\hline \multicolumn{6}{|l|}{ Independent Variables } \\
\hline \multirow[t]{2}{*}{ Age } & 16.009 & 16.003 & 15.993 & 15.987 & 15.971 \\
\hline & $(1.254)$ & $(1.250)$ & $(1.251)$ & $(1.250)$ & $(1.248)$ \\
\hline \multirow[t]{2}{*}{ Male } & 0.486 & 0.486 & 0.485 & 0.485 & 0.485 \\
\hline & $(0.500)$ & $(0.500)$ & $(0.500)$ & $(0.500)$ & $(0.500)$ \\
\hline \multirow[t]{2}{*}{ Black } & 0.155 & 0.152 & 0.149 & 0.147 & 0.149 \\
\hline & $(0.362)$ & $(0.359)$ & $(0.357)$ & $(0.354)$ & $(0.356)$ \\
\hline \multirow[t]{2}{*}{ Hispanic } & 0.103 & 0.100 & 0.100 & 0.098 & 0.093 \\
\hline & $(0.303)$ & $(0.300)$ & $(0.301)$ & $(0.298)$ & $(0.290)$ \\
\hline \multirow[t]{2}{*}{ Asian } & 0.032 & 0.032 & 0.034 & 0.035 & 0.037 \\
\hline & $(0.175)$ & $(0.177)$ & $(0.181)$ & $(0.184)$ & $(0.189)$ \\
\hline \multirow[t]{2}{*}{ Other Race } & 0.078 & 0.089 & 0.099 & 0.111 & 0.122 \\
\hline & $(0.268)$ & $(0.285)$ & $(0.299)$ & $(0.315)$ & $(0.327)$ \\
\hline \multirow[t]{2}{*}{ Grade } & 10.306 & 10.306 & 10.311 & 10.319 & 10.325 \\
\hline & $(1.291)$ & $(1.280)$ & $(1.272)$ & $(1.268)$ & $(1.263)$ \\
\hline \multirow[t]{2}{*}{ Cigarette Taxes (2005\$) } & 0.556 & 0.638 & 0.752 & 0.866 & 0.957 \\
\hline & $(0.446)$ & $(0.505)$ & $(0.616)$ & $(0.734)$ & $(0.776)$ \\
\hline \multirow[t]{2}{*}{ Unemployment Rates } & 0.050 & 0.049 & 0.055 & 0.059 & 0.061 \\
\hline & $(0.013)$ & $(0.012)$ & $(0.019)$ & $(0.021)$ & $(0.020)$ \\
\hline $\mathrm{N}$ & 512,793 & 622,299 & 749,976 & 880,091 & $1,042,296$ \\
\hline
\end{tabular}

Notes: Unweighted means are reported. Standard deviations are in parentheses. 
Appendix Table 4. Logit Estimates of the Relationship between Cigarette Taxes and Youth Smoking Using State YRBS Data

\begin{tabular}{lccccc}
\hline & $\begin{array}{c}1991-2005 \\
(1)\end{array}$ & $\begin{array}{c}1991-2007 \\
(2)\end{array}$ & $\begin{array}{c}1991-2009 \\
(3)\end{array}$ & $\begin{array}{c}1991-2011 \\
(4)\end{array}$ & $\begin{array}{c}1991-2013 \\
(5)\end{array}$ \\
\hline \multicolumn{1}{l}{ Panel I: Smoking Participation } & & & & \\
\hline Cig Tax & $-.026^{* * *}$ & $-.015^{*}$ & $-.016^{* * *}$ & $-.012^{* *}$ & $-.010^{* *}$ \\
& $(.009)$ & $(.009)$ & $(.006)$ & $(.005)$ & $(.005)$ \\
Mean & .267 & .251 & .237 & .224 & .208 \\
$\begin{array}{l}\text { Semi- } \\
\text { elasticity }\end{array}$ & -9.72 & -5.97 & -6.75 & -5.37 & -4.81
\end{tabular}

\section{Panel II: Frequent Smoking}

\begin{tabular}{lccccc}
\hline Cig Tax & $\begin{array}{l}.019 * * * \\
(.006)\end{array}$ & $\begin{array}{c}-.011 * * \\
(.005)\end{array}$ & $\begin{array}{c}-.009 * * * \\
(.003)\end{array}$ & $\begin{array}{c}-.008 * * * \\
(.003)\end{array}$ & $\begin{array}{c}-.007 * * * \\
(.003)\end{array}$ \\
Mean & .128 & .119 & .109 & .101 & .092 \\
$\begin{array}{l}\text { Semi- } \\
\text { elasticity }\end{array}$ & -14.80 & -9.26 & -8.22 & -7.90 & -7.63 \\
& & & & & \\
State and year & yes & yes & yes & yes & yes \\
FEs & & & & & \\
$\mathrm{N}$ & 409,385 & 505,823 & 618,303 & 734,034 & 883,691 \\
\hline
\end{tabular}

* Statistically significant at $10 \%$ level; ** at $5 \%$ level; *** at $1 \%$ level.

Notes: Marginal effects based on unweighted state YRBS data are reported. All regressions include the unemployment rate, clean air laws, demographics, and state and year fixed effects. Standard errors clustered by state are in parentheses. 
Appendix Table 5. Logit Estimates of the Relationship between Cigarette Taxes and Youth Smoking Using National YRBS Data

\begin{tabular}{|c|c|c|c|c|c|}
\hline & $\begin{array}{c}1991-2005 \\
\text { (1) }\end{array}$ & $\begin{array}{c}1991-2007 \\
\text { (2) }\end{array}$ & $\begin{array}{c}1991-2009 \\
\text { (3) }\end{array}$ & $\begin{array}{c}1991-2011 \\
\text { (4) }\end{array}$ & $\begin{array}{c}1991-2013 \\
\text { (5) }\end{array}$ \\
\hline \multicolumn{6}{|c|}{ Panel I: Smoking Participation } \\
\hline Cig Tax & $\begin{array}{c}-.046 * * * \\
(.022)\end{array}$ & $\begin{array}{l}-.033 * * * \\
(.017)\end{array}$ & $\begin{array}{l}-.031 * * * \\
(.013)\end{array}$ & $\begin{array}{l}-.026 * * * \\
(.011)\end{array}$ & $\begin{array}{l}-.028 * * * \\
(.009)\end{array}$ \\
\hline Mean & .297 & .286 & .276 & .267 & .258 \\
\hline $\begin{array}{l}\text { Semi- } \\
\text { elasticity }\end{array}$ & -15.48 & -11.53 & -11.23 & -9.75 & -10.85 \\
\hline \multicolumn{6}{|c|}{ Panel II: Frequent Smoking } \\
\hline Cig Tax & $\begin{array}{c}-.026^{*} \\
(.014)\end{array}$ & $\begin{array}{l}-.022^{*} \\
(.012)\end{array}$ & $\begin{array}{c}-.022 * * * \\
(.008)\end{array}$ & $\begin{array}{c}-.016 * * \\
(.007)\end{array}$ & $\begin{array}{c}-.016 * * * \\
(.006)\end{array}$ \\
\hline Mean & .136 & .13 & .124 & .118 & .113 \\
\hline $\begin{array}{l}\text { Semi- } \\
\text { elasticity }\end{array}$ & -19.06 & -16.88 & -17.76 & -13.56 & -14.14 \\
\hline $\begin{array}{l}\text { State/year } \\
\text { FEs }\end{array}$ & yes & yes & yes & yes & yes \\
\hline $\mathrm{N}$ & 103,408 & 116,476 & 131,673 & 146,057 & 158,605 \\
\hline
\end{tabular}

* Statistically significant at $10 \%$ level; ** at $5 \%$ level; *** at $1 \%$ level.

Notes: Marginal effects based on weighted national YRBS data are reported. All regressions include the unemployment rate, clean air laws, demographics, and state and year fixed effects. Standard errors clustered by state are in parentheses. 
Appendix Table 6. Logit Estimates of the Relationship between Cigarette Taxes and Youth Smoking Using Combined State and National YRBS Data

\begin{tabular}{|c|c|c|c|c|c|}
\hline & $\begin{array}{c}1991-2005 \\
(1) \\
\end{array}$ & $\begin{array}{c}1991-2007 \\
(2) \\
\end{array}$ & $\begin{array}{c}1991-2009 \\
(3) \\
\end{array}$ & $\begin{array}{c}1991-2011 \\
(4) \\
\end{array}$ & $\begin{array}{c}1991-2013 \\
(5) \\
\end{array}$ \\
\hline \multicolumn{6}{|c|}{ Panel I: Smoking Participation } \\
\hline Cig Tax & $\begin{array}{c}-.030 * * * \\
(.008)\end{array}$ & $\begin{array}{c}-.019 * * \\
(.007)\end{array}$ & $\begin{array}{c}-.018 * * * \\
(.005)\end{array}$ & $\begin{array}{l}-.014 * * * \\
(.005)\end{array}$ & $\begin{array}{c}-.011 * * \\
(.005)\end{array}$ \\
\hline Mean & 0.269 & 0.254 & 0.241 & 0.228 & 0.213 \\
\hline $\begin{array}{l}\text { Semi- } \\
\text { elasticity }\end{array}$ & -11.15 & -7.47 & -7.48 & -6.13 & -5.15 \\
\hline \multicolumn{6}{|c|}{ Panel II: Frequent Smoking } \\
\hline Cig Tax & $\begin{array}{c}-.019 * * * \\
(.004)\end{array}$ & $\begin{array}{c}-.012 * * * \\
(.004)\end{array}$ & $\begin{array}{c}-.010 * * * \\
(.002)\end{array}$ & $\begin{array}{l}-.009 * * * \\
(.003)\end{array}$ & $\begin{array}{c}-.007 * * * \\
(.002)\end{array}$ \\
\hline Mean & 0.125 & 0.117 & 0.108 & 0.101 & 0.092 \\
\hline $\begin{array}{l}\text { Semi- } \\
\text { elasticity }\end{array}$ & -15.19 & -10.28 & -9.22 & -8.91 & -7.57 \\
\hline $\begin{array}{l}\text { State and } \\
\text { Year FEs }\end{array}$ & yes & yes & yes & yes & yes \\
\hline $\mathrm{N}$ & 512,793 & 622,299 & 749,976 & 880,091 & $1,042,296$ \\
\hline
\end{tabular}




\section{Appendix Table 7. Logit Estimates of the Relationship between Cigarette Taxes and Youth Smoking Using Unweighted National YRBS Data}

\begin{tabular}{|c|c|c|c|}
\hline & 1991-2005 & $1991-2013$ & $2007-2013$ \\
\hline \multicolumn{4}{|l|}{ Panel I: Smoking Participation } \\
\hline Cig Tax & $\begin{array}{l}-.038^{*} \\
(.020)\end{array}$ & $\begin{array}{l}-.034 * * \\
(.018)\end{array}$ & $\begin{array}{c}0.007 \\
(0.016)\end{array}$ \\
\hline Mean & .272 & .239 & .175 \\
\hline Semi-elasticity & -13.96 & -7.97 & 4.00 \\
\hline Test of equality across periods & \multicolumn{3}{|c|}{$\mathrm{z}$-value $=1.54(\mathrm{p}$-value $=0.123)$} \\
\hline \multicolumn{4}{|l|}{ Panel II: Frequent Smoking } \\
\hline Cig Tax & $\begin{array}{l}-.019 \\
(.012)\end{array}$ & $\begin{array}{l}-.012 * * * \\
(0.004)\end{array}$ & $\begin{array}{c}0.002 \\
(0.007)\end{array}$ \\
\hline Mean & .108 & .092 & .060 \\
\hline Semi-elasticity & -17.53 & -13.10 & 3.33 \\
\hline Test of equality across periods & \multicolumn{3}{|c|}{$\mathrm{z}$-value $=1.26(\mathrm{p}$-value $=0.208)$} \\
\hline Year and state fixed effects & yes & yes & yes \\
\hline $\mathrm{N}$ & 103,408 & 158,605 & 55,197 \\
\hline \multicolumn{4}{|c|}{$*$ Statistically significant at $10 \%$ level; $* *$ at $5 \%$ level; $* * *$ at $1 \%$ level. } \\
\hline \multicolumn{4}{|c|}{$\begin{array}{l}\text { Notes: Marginal effects based on unweighted national YRBS data are reported. All regressions include the } \\
\text { unemployment rate, clean air laws, demographics, and state and year fixed effects. Standard errors clustered by } \\
\text { state are in parentheses. }\end{array}$} \\
\hline
\end{tabular}




\section{Appendix Table 8. Logit Estimates of the Relationship between Cigarette Taxes and Youth Smoking Controlling for State-Specific Quadratic Time Trends}

\begin{tabular}{lccc} 
& $1991-2005$ & $1991-2013$ & $2007-2013$ \\
\hline Panel I: Smoking Participation & & & \\
Cig Tax & -.009 & .002 & -.005 \\
& $(.013)$ & $.010)$ & $.008)$ \\
Mean & .269 & .212 & -158 \\
Semi-elasticity & -3.35 & .94 & \\
Test of equality across periods & \multicolumn{2}{c}{ z-value $=1.01(\mathrm{p}$-value $=.310)$} \\
\hline
\end{tabular}

\section{Panel II: Frequent Smoking}

Cig Tax

.001

$(.009)$

.125

0.80

z-value $=.22(\mathrm{p}$-value $=.824)$

Test of equality across periods

Year and state fixed effects

State-specific quadratic trends yes

yes
.001

$(.005)$

.092

1.09

5.00

$\mathrm{N}$
* Statistically significant at 10\% level; ** at 5\% level; $* * *$ at $1 \%$ level.
Notes: Marginal effects based on unweighted state and national YRBS data are reported. All regressions include
the unemployment rate, clean air laws, demographics, and state and year fixed effects. Standard errors clustered
by state are in parentheses.




\section{Appendix Table 9. Logit Estimates of the Relationship between Cigarette Taxes and Youth Smoking Controlling for Region-Year Interactions}

$1991-2005$

\section{Panel I: Smoking Participation}

Cig Tax

.269

$-3.35$

$\mathrm{z}$-value $=-0.81(\mathrm{p}$-value $=.417)$

Mean

$1991-2013$

Semi-elasticity

Test of equality across periods

3

$-0.010 * *$

(.004)

$-.004$

$(.005)$

.212

.158

$-2.53$

\section{Panel II: Frequent Smoking}

Cig Tax

$-.004$

$-0.006 * * *$

$-.002$

$(.003)$

(.002)

(.003)

Mean

.125

.092

.060

Semi-elasticity

$-3.20$

$-6.52$

$-3.33$

Test of equality across periods

$\mathrm{z}$-value $=0.58(\mathrm{p}$-value $=.564)$

State fixed effects

Region-year interactions

yes

yes yes

yes yes

yes

\footnotetext{
$\mathrm{N}$

512,793

$1,042,296$

* Statistically significant at $10 \%$ level; ** at $5 \%$ level; *** at $1 \%$ level.

Notes: Marginal effects based on unweighted state and national YRBS data are reported. All regressions include the unemployment rate, clean air laws, demographics, and state fixed effects and three U.S. Census Region indicators (Northeast, Midwest, West) interacted with year. Standard errors clustered by state are in parentheses.
} 